\title{
Purple Gem Spinel from Vietnam and AfGHANISTAN: COMPARISON OF TRACE Element Chemistry, Cause of Color, AND INCLUSIONS
}

Philippe M. Belley and Aaron C. Palke

This study compares two purple gem spinel samples with regard to trace element chemistry and visible light absorption spectra, and presents the first reported example of a spinel with a saturated purple color caused predominantly by chromium and cobalt. Sample VN, from a placer deposit in the Luc Yen district of Vietnam, exhibited strong saturation, orange-red fluorescence in UV, and magnesite and graphite inclusions. Sample AF was from Badakhshan, Afghanistan, with light to medium saturation and containing phlogopite, amphibole, and probable fluid inclusions. UV-Vis-NIR spectra are compared along with trace element chemistry. Sample VN is colored primarily by cobalt (17.9 ppma) and chromium (593 ppma), with minor color contribution from Fe (2437 ppma), and contains significantly more cobalt than typical Cr-enriched red, pink, and purple gem spinels ( $<6$ ppma Co). The dominant contributions of chromophores $\mathrm{Cr}^{3+}$ and $\mathrm{Co}^{2+}$ to the color of sample $\mathrm{VN}$ are responsible for its higher color saturation than that of sample AF, which is colored dominantly by $\mathrm{Fe}^{2+}$ and $\mathrm{Fe}^{3+}$ (3089 ppma total Fe) and contains negligible concentrations of other chromophores $\left(<10 \mathrm{ppma} \mathrm{V}^{3+}, \mathrm{Cr}^{3+}\right.$, and $\left.\mathrm{Co}^{2+}\right)$. In the Vietnamese purple spinel, the relatively low Fe concentration is likely crucial in creating the attractive saturated color. This sample is enriched in $\mathrm{Co}, \mathrm{Ni}, \mathrm{Cr}, \mathrm{V}, \mathrm{Zn}$, and $\mathrm{Ga}$. In contrast, the purple spinel from Afghanistan is relatively impoverished in all trace elements except Fe and $\mathrm{Mn}$. Sample VN represents an approximate intermediate between natural gem spinel populations colored dominantly by $\mathrm{Cr}^{3+}$ vs. dominantly by $\mathrm{Co}^{2+}$. $\mathrm{Cr}^{3+}-,\left(\mathrm{Fe}^{2+}, \mathrm{Fe}^{3+}\right)-$, and $\mathrm{Co}^{2+}$-dominant (in terms of color) gem spinels are easily differentiated by chemical composition using a discrimination plot of $\mathrm{Co} / \mathrm{Cr}$ vs. $\mathrm{Co} / \mathrm{Fe}$, but this is not valid for spinel dominantly colored by $\mathrm{V}^{3+}$ or containing significant concentrations of Fe.

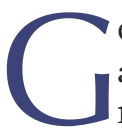
em-quality spinel occurs in a variety of colors as a result of a diverse array of possible chromophores and chromophore combinations (Schmetzer et al., 1989; Andreozzi et al., 2019): combinations of $\mathrm{Fe}^{2+}$ and $\mathrm{Fe}^{3+}$ (light blue/violet to green to black with increasing Fe concentration; Hålenius et al., 2002); $\mathrm{Co}^{2+}$ (blue; Shigley and Stockton, 1984; D'Ippolito et al., 2015); $\mathrm{Cr}^{3+}$ (red); and V ${ }^{3+}$ (orange; Andreozzi et al., 2019). Vivid spinels colored by cobalt (blue) and chromium (red) are particularly sought after in the gem trade. Purple spinel (figure 1) is generally colored by Fe or by a combination of $\mathrm{Cr}, \mathrm{V}$, and

See end of article for About the Authors and Acknowledgments.

Gems \& Gemologr, Vol. 57, No. 3, pp. 228-238,

http://dx.doi.org/10.5741/GEMS.57.3.228

(C) 2021 Gemological Institute of America subordinate Fe (Andreozzi et al., 2019). The current study compares the chemical composition and color of two purple spinel samples, from Vietnam and Afghanistan (figure 2), to each other and in the

\section{In Brief}

- A purple sample from the Luc Yen district of Vietnam is colored primarily by $\mathrm{Co}^{2+}$ and $\mathrm{Cr}^{3+}$, with only minor contribution of $\mathrm{Fe}^{2+}$ and $\mathrm{Fe}^{3+}$ to visible light absorption.

- In contrast, a purple spinel from Badakhshan, Afghanistan, is colored exclusively by $\mathrm{Fe}^{2+}$ and $\mathrm{Fe}^{3+}$, containing negligible concentrations of other chromophores.

- Purple coloration of spinel caused by a combination of $\mathrm{Co}^{2+}$ and $\mathrm{Cr}^{3+}$ is more saturated than that caused by $\mathrm{Fe}^{2+} / \mathrm{Fe}^{3+}$ 


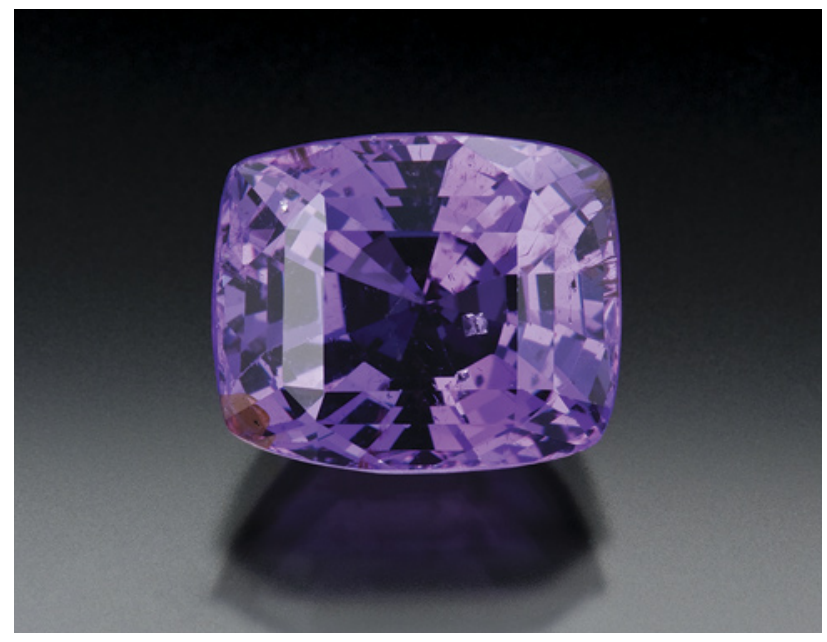

Figure 1. The vivid colors seen in fine gem-quality spinel are derived from the mixing between multiple different chromophores in a range of ratios and concentrations, as in this fine 13.52 ct violetish purple spinel. Courtesy of the Dr. Edward J. Gübelin Collection. Photo by Robert Weldon/GIA.

broader context of all gem spinel. One is a saturated purple sample from a placer deposit near Khao Ka in the Luc Yen district of Vietnam (figure 3). The second

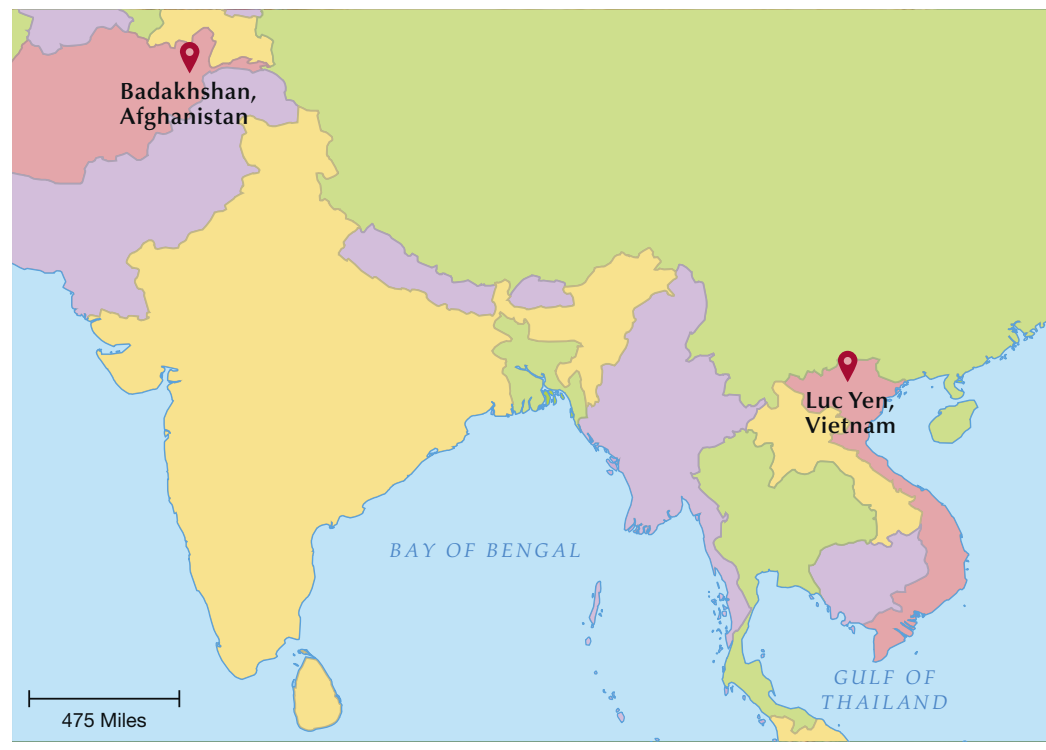

Figure 2. Map of Asia showing the geographic origin of the two spinel samples: Badakhshan Province in Afghanistan and the Luc Yen district of Vietnam.

sample is a purple spinel with light to medium saturation, mined from a marble-hosted deposit in Badakhshan, Afghanistan (figure 4).

Figure 3. This placer deposit, the source of sample VN, is situated in rice paddies at Khao Ka in the Luc Yen district of Vietnam. Photo courtesy of Geir Gussiås (Balder Gems), 2017.

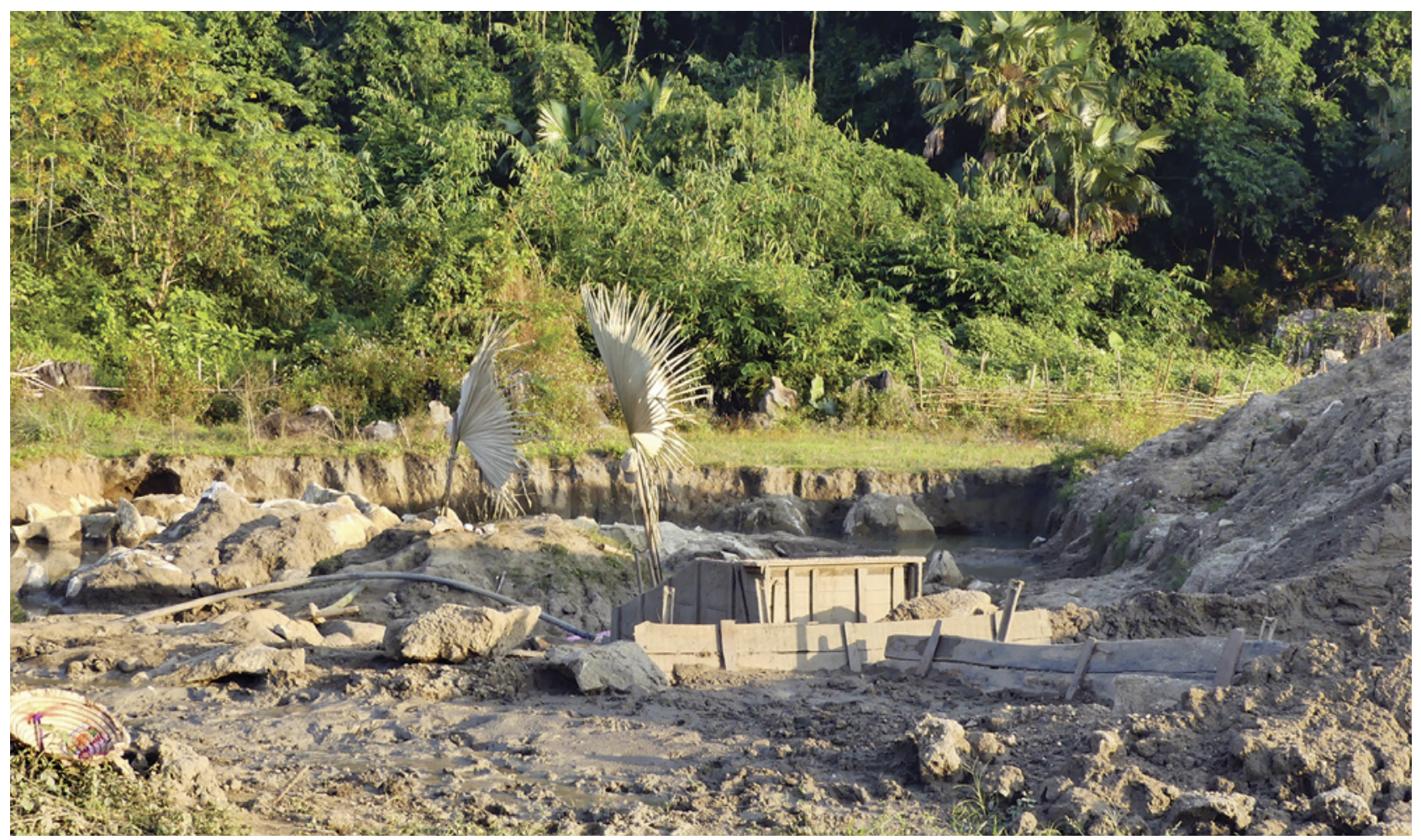




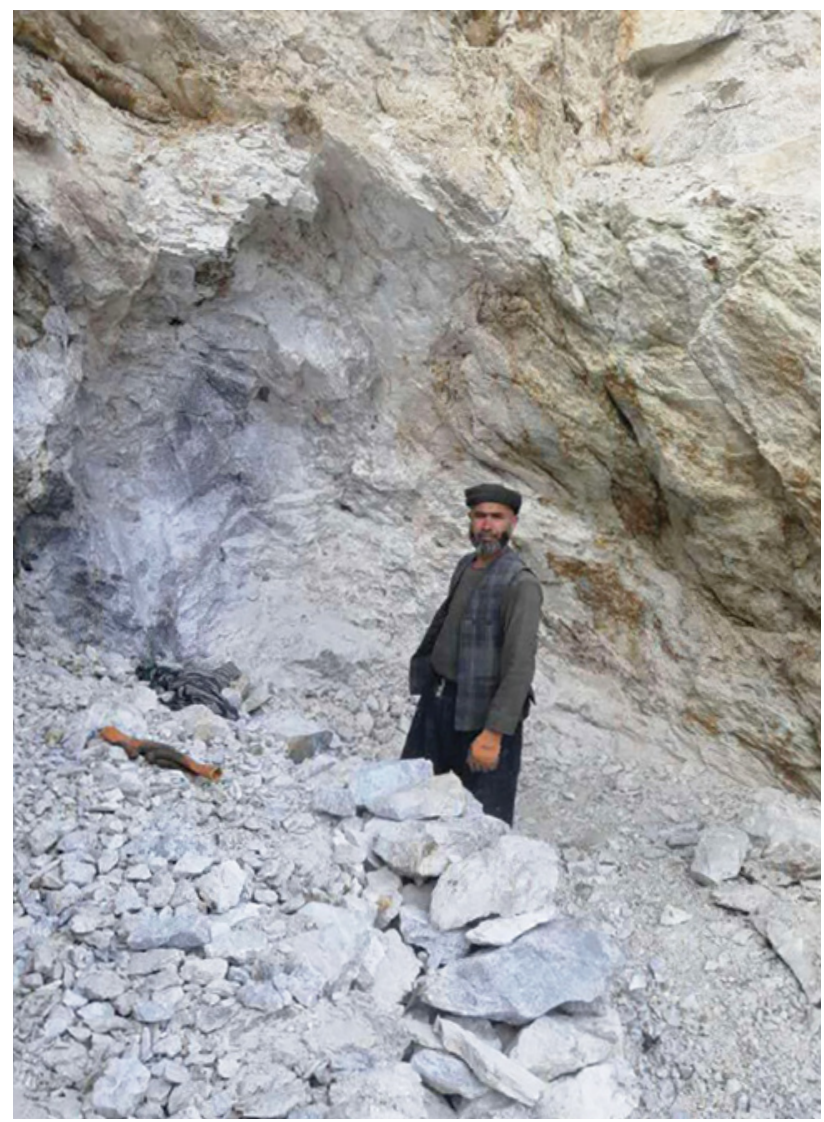

Figure 4. The purple spinel deposit in Badakhshan, Afghanistan. Photo courtesy of Ikram Muhammad and ANAAR Gems, 2017.

\section{MATERIALS AND METHODS}

Materials. The Vietnamese spinel (sample VN, figure 5) was acquired from Geir Atle Gussiås and Mai Tran of Balder Gems. They purchased it from miners onsite at the Khao Ka alluvial deposit, northeast of Nà

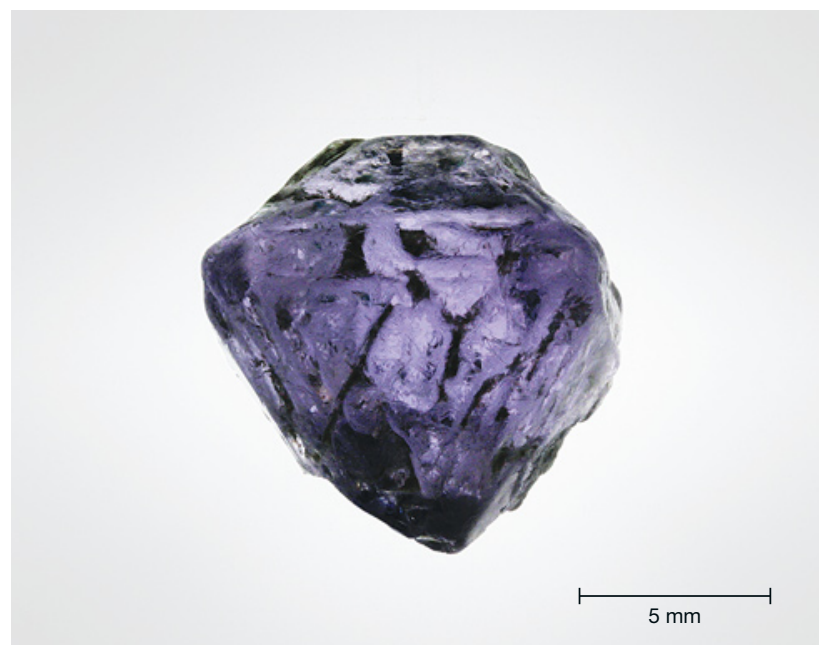

Figure 6. Spinel sample AF from Badakhshan, Afghanistan. Photo by Aaron Palke.

Hà, An Phú, in the Luc Yen district (approx. $21^{\circ} 58^{\prime} 54.37^{\prime \prime} \mathrm{N}, 104^{\circ} 50^{\prime} 44.77^{\prime \prime} \mathrm{E}$; see also Chauviré et al., 2015). Mr. Gussiås suspected that the spinel sample was enriched in both cobalt and chromium due to its unusual color; he has reported a similarly saturated purple stone, faceted and just under 2 ct from the same placer locality. The Luc Yen region is underlain by supracrustal metamorphic rocks including significant quantities of marble, the typical source rock for gem spinel (Chauviré et al., 2015 and references therein). The purple spinel (sample AF, figure 6) from a metacarbonate outcrop in the Badakhshan Province of Afghanistan (the "Parawara mine" in Boehm, 2017) was mined in 2017 and donated by gem and mineral dealer Ikram Muhammad. Samples VN

Figure 5. Spinel sample VN from the Luc Yen district, Vietnam $(12.5 \times 5.0 \mathrm{~mm})$. A: In daylight (left) and incandescent (right) illumination. B: In long-wave UV (365 nm). Photos by Aaron Palke.

A

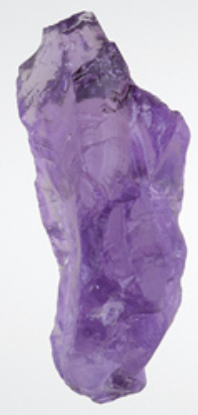

\section{B}

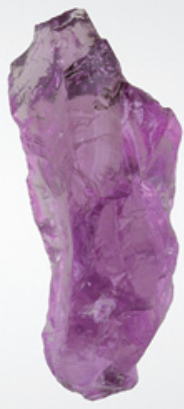

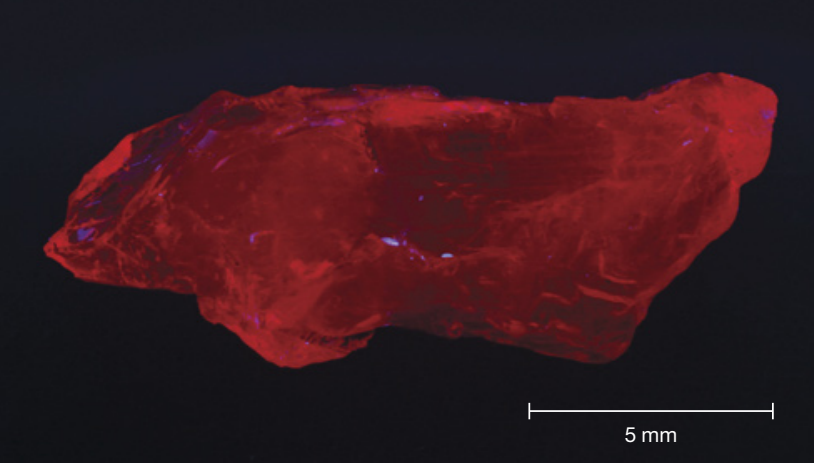



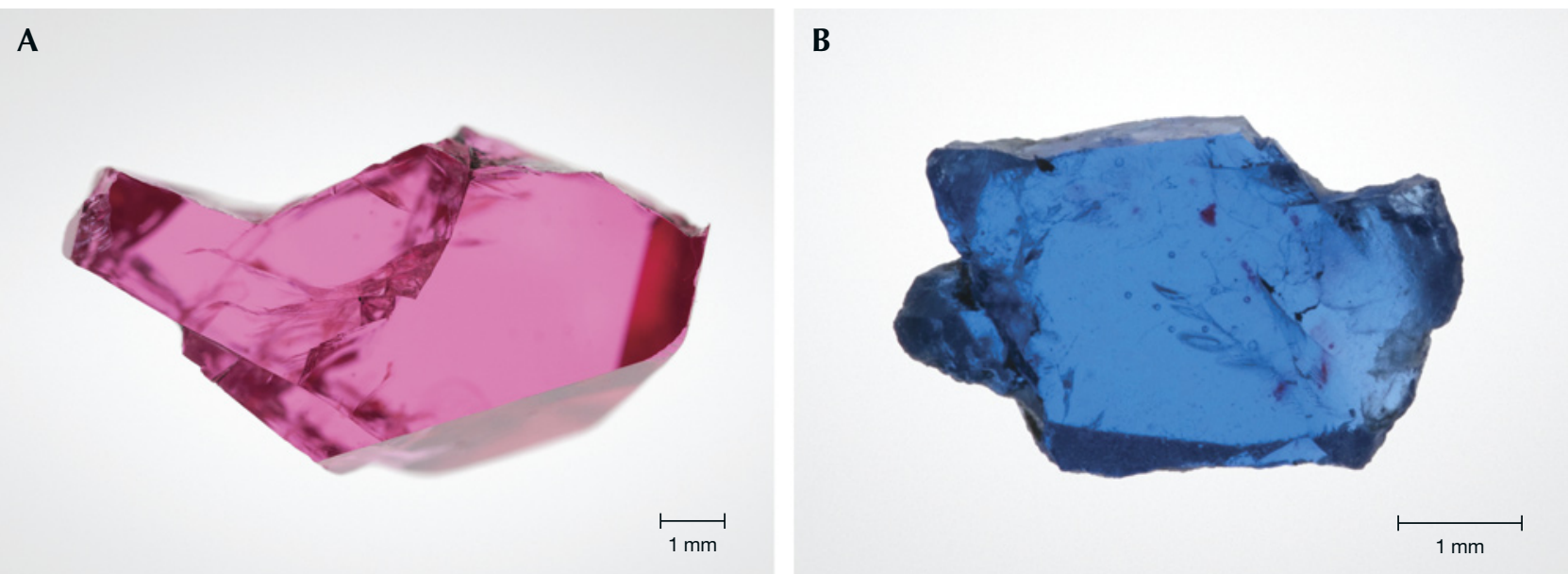

Figure 7. GIA reference samples GIA-Cr (A, $2.641 \mathrm{~mm}$ thick) and GIA-Co (B, $1.053 \mathrm{~mm}$ thick). Photos by Aaron Palke.

and AF were flat-polished for UV-Vis spectrometry at GIA's Carlsbad laboratory, with thicknesses of 2.155 $\mathrm{mm}$ and $4.486 \mathrm{~mm}$, respectively.

Two spinel samples from the GIA collection provided reference $\mathrm{UV}$-Vis spectra of $\mathrm{Co}^{2+}$-dominant, and $\mathrm{Cr}^{3+}$-dominant spinel color end members for use in assessing the color contribution of these chromophores in sample VN. The spinel dominantly colored by $\mathrm{Cr}^{3+}$ is vivid pink (GIA sample 100305165116, $2.641 \mathrm{~mm}$ thick, named "GIA-Cr"; figure $7 \mathrm{~A}$ ) and the spinel dominantly colored by $\mathrm{Co}^{2+}$ is vivid blue (GIA sample 100305162587, $1.053 \mathrm{~mm}$ thick, named "GIA-Co"; figure 7B).

Methods. Electron Probe Microanalysis (EPMA). For EPMA analysis, the samples were mounted in epoxy pucks and polished. Chemical compositions were obtained with a JEOL JXA-8230 electron microprobe (University of Ottawa) in wavelength-dispersion (WD) mode. The operating voltage was $20 \mathrm{kV}$, with $20 \mathrm{nA}$ beam current and $5 \mu \mathrm{m}$ beam diameter. Counts were collected for 20 seconds for each element. The following standards were used (all $\mathrm{K} \alpha)$ : hematite $(\mathrm{Fe})$, chromite $(\mathrm{Cr}, \mathrm{Co}, \mathrm{Al}, \mathrm{Mg})$, rutile $(\mathrm{Ti})$, tephroite $(\mathrm{Mn})$, pentlandite $(\mathrm{Ni})$, vanadinite $(\mathrm{V})$, and gahnite (Zn). Matrix correction calculations were performed using the Armstrong/Love-Scott $\varphi(\rho Z)$ method (Armstrong, 1988). Limits of detection were 0.01 wt. \% $\left(\mathrm{MgO}, \mathrm{Al}_{2} \mathrm{O}_{3}\right), 0.02$ wt. $\%\left(\mathrm{~V}_{2} \mathrm{O}_{3}\right)$, and 0.03 wt. $\%\left(\mathrm{Cr}_{2} \mathrm{O}_{3}, \mathrm{FeO}, \mathrm{CoO}, \mathrm{NiO}, \mathrm{MnO}\right)$.

Trace Element Analysis. Laser ablation-inductively coupled plasma-mass spectrometry (LA-ICP-MS) analyses of samples $\mathrm{VN}$ and $\mathrm{AF}$ were performed using a $193 \mathrm{~nm}$ ArF excimer laser ablation system (ASI Aus- tralia RESOlution M-50-LR) connected to an Agilent 7700x quadrupole ICP-MS at the Pacific Centre for Isotopic and Geochemical Research at the University of British Columbia in Vancouver, Canada. Measurements were performed for $40 \mathrm{~s}$ at a laser repetition rate of $5 \mathrm{~Hz}, 20 \mathrm{~ns}$ pulse width, using a spot size of 89 $\mu \mathrm{m}$. On-sample fluence was $3 \mathrm{~J} / \mathrm{cm}^{2}$. Ablation was carried out under a helium atmosphere. A mixture of $\mathrm{He}$ (from the sample cell) and Ar served as carrier gas and was admixed with $\mathrm{N}_{2}$ for signal enhancement. The mass spectrometer was tuned for sensitivity, $\mathrm{ThO} / \mathrm{Th}<0.2 \%$ and a mass bias with $238 / 232 \approx 101 \%$. Spots were pre-ablated to remove surface contamination, followed by $40 \mathrm{~s}$ of ablation and a $30 \mathrm{~s}$ washout time. The following masses were collected: ${ }^{7} \mathrm{Li},{ }^{9} \mathrm{Be}$, ${ }^{11} \mathrm{~B},{ }^{49} \mathrm{Ti},{ }^{51} \mathrm{~V},{ }^{53} \mathrm{Cr},{ }^{55} \mathrm{Mn},{ }^{56} \mathrm{Fe},{ }^{59} \mathrm{Co},{ }^{60} \mathrm{Ni},{ }^{67} \mathrm{Zn}$, and ${ }^{69} \mathrm{Ga}$. Measurements on the following elements were collected but not detected in the spinel samples: $\mathrm{Sc}, \mathrm{Cu}$, $\mathrm{Sr}, \mathrm{Y}, \mathrm{Zr}, \mathrm{Hf}, \mathrm{Ta}$, and rare earth elements. Calibration was carried out by standard-sample bracketing using the silicate glass SRM NIST 610 as the external standard and ${ }^{25} \mathrm{Mg}$ as the internal standard using values from EPMA (table 1). USGS basalt glass reference material BCR-2G (Rocholl, 2007) was cross-checked for quality control and was within the range consistent with values in the GeoReM database (Jochum et al., 2005). The coefficient of variation for individual trace element measurements in BCR-2G is $\leq 6 \%$, with the exception of Be $(\sim 11 \%)$ and $\mathrm{B}(\sim 38 \%)$. Measured B concentrations varied unpredictably despite drift correction, and thus the data was rejected. Data reduction was performed using the Iolite v.3.0 software (Paton et al., 2011).

LA-ICP-MS trace element data was collected for samples GIA-Cr and GIA-Co at GIA using a Thermo 


\begin{tabular}{|c|c|c|c|c|}
\hline Sample no. & \multicolumn{2}{|c|}{ VN } & \multicolumn{2}{|c|}{$\mathrm{AF}$} \\
\hline Color & \multicolumn{2}{|c|}{ Purple } & \multicolumn{2}{|c|}{ Purple } \\
\hline Origin & \multicolumn{2}{|c|}{ Khao Ka, Vietnam } & \multicolumn{2}{|c|}{ Badakhshan, Afghanistan } \\
\hline No. of spots & \multicolumn{2}{|c|}{4} & \multicolumn{2}{|c|}{3} \\
\hline & Weight $\%$ & SD & Weight \% & SD \\
\hline $\mathrm{MgO}$ & 26.17 & 0.10 & 26.69 & 0.09 \\
\hline $\mathrm{Al}_{2} \mathrm{O}_{3}$ & 70.85 & 0.25 & 71.50 & 0.14 \\
\hline $\mathrm{TiO}_{2}$ & 0.01 & 0.01 & 0.01 & 0.01 \\
\hline $\mathrm{V}_{2} \mathrm{O}_{3}$ & 0.03 & 0.01 & $<0.02$ & \\
\hline $\mathrm{Cr}_{2} \mathrm{O}_{3}$ & 0.22 & 0.02 & $<0.03$ & \\
\hline $\mathrm{MnO}$ & $<0.03$ & & $<0.03$ & \\
\hline $\mathrm{FeO}$ & 0.86 & 0.02 & 1.08 & 0.01 \\
\hline $\mathrm{CoO}$ & $<0.03$ & & $<0.03$ & \\
\hline $\mathrm{NiO}$ & $<0.03$ & & $<0.03$ & \\
\hline $\mathrm{ZnO}$ & 1.44 & 0.05 & $<0.03$ & \\
\hline Total & 99.58 & & 99.28 & \\
\hline \multicolumn{5}{|c|}{ Normalized to 32 oxygens } \\
\hline $\mathrm{Mg}$ & 7.504 & & 7.620 & \\
\hline $\mathrm{Al}$ & 16.062 & & 16.137 & \\
\hline $\mathrm{Ti}$ & 0.001 & & 0.001 & \\
\hline V & 0.005 & & - & \\
\hline $\mathrm{Cr}$ & 0.033 & & - & \\
\hline $\mathrm{Mn}$ & - & & - & \\
\hline $\mathrm{Fe}$ & 0.138 & & 0.173 & \\
\hline $\mathrm{Co}$ & - & & - & \\
\hline $\mathrm{Ni}$ & - & & - & \\
\hline $\mathrm{Zn}$ & 0.205 & & - & \\
\hline$\sum_{\text {cations }}$ & 23.948 & & 23.931 & \\
\hline
\end{tabular}

$S D=$ standard deviation

Limits of detection (wt. \%): $0.01\left(\mathrm{MgO}, \mathrm{Al}_{2} \mathrm{O}_{3}\right), 0.02\left(\mathrm{~V}_{2} \mathrm{O}_{3}\right)$, and 0.03 $\left(\mathrm{Cr}_{2} \mathrm{O}_{3}, \mathrm{FeO}, \mathrm{CoO}, \mathrm{NiO}, \mathrm{MnO}\right)$

iCap-Q ICP-MS coupled to an Elemental Scientific Lasers NWR213 nm laser ablation system with a frequency-quintupled Nd:YAG laser $(213 \mathrm{~nm}$ wavelength with 4 ns pulse width). Ablation was carried out with $55 \mu \mathrm{m}$ spot sizes with fluence around $8 \pm 1$ $\mathrm{J} / \mathrm{cm}^{2}$ and a $15 \mathrm{~Hz}$ repetition rate. NIST 610 and 612 glasses were used as external standards with ${ }^{24} \mathrm{Mg}$ set as the internal standard with a value assigned at 17.08 wt. \%. Masses analyzed include ${ }^{7} \mathrm{Li},{ }^{9} \mathrm{Be},{ }^{47} \mathrm{Ti},{ }^{51} \mathrm{~V},{ }^{52} \mathrm{Cr}$, ${ }^{55} \mathrm{Mn},{ }^{56} \mathrm{Fe},{ }^{59} \mathrm{Co},{ }^{60} \mathrm{Ni},{ }^{66} \mathrm{Zn}$, and ${ }^{69} \mathrm{Ga}$. The trace element compositions of GIA reference samples are reported in table 2.

Parts per million by weight (ppmw) values were converted to parts per million atoms (ppma) using the following formula:

$[$ ppma $]=[\mathrm{ppmw}] \times(\mathrm{mol}$. wt. of spinel $) /(7 \times$ atomic wt. of element $)$

where 7 is the total number of atoms in one formula unit of spinel.
Spectrophotometry. Ultraviolet/visible/near-infrared (UV-Vis-NIR) absorption spectra were measured using a custom-built setup equipped with an Ocean Optics HR4000 CCD spectrometer and an Avantes light source incorporating both halogen and deuterium light sources. Light was transmitted to the sample placed at the entrance to an integrating sphere and then to the detector using fiber-optic cables. Data was collected with one accumulation using an integration time of $10 \mathrm{~s}$ at wavelength interval of $0.76 \mathrm{~nm}$ and spectral resolution of $0.90 \mathrm{~nm}$ from 300 to $800 \mathrm{~nm}$.

Reference Spectra and Absorption Peak Assignment. The UV-Vis spectrum for purple spinel sample VN was compared to two reference spectra: a Cr-dominant spinel spectrum (vivid pink, GIA-Cr) and a Codominant spinel spectrum (vivid blue, GIA-Co). The spectra were selected for their highly dominant absorption signature by the chromophore of interest with negligible absorption by other chromophores. The spectra contain very small $\mathrm{Fe}^{2+}$ absorption peaks that were imperceptible when the spectra were scaled down for data processing.

The reference chromophore absorption peaks (wavelength in $\mathrm{nm}$ ) are averages for $\mathrm{Mg}-\mathrm{Al}$ spinel samples reported by Andreozzi et al. (2019) and D'Ip-

TABLE 2. LA-ICP-MS analyses of trace element concentrations in samples used for $\mathrm{Cr}$ and $\mathrm{Co}$ reference spectra.

\begin{tabular}{|c|c|c|c|c|c|c|c|}
\hline Sample & & GIA-Cr & & & GIA-Co & & \\
\hline Color & & ivid pin & & & ivid blu & & Detection \\
\hline No. of spots & & 6 & & & 3 & & \\
\hline & Avg. & Avg. & SD & Avg. & Avg. & SD & \\
\hline & ppmw & ppma & ppma & ppmw & ppma & ppma & ppmw \\
\hline $\mathrm{Li}$ & 11.0 & 32.1 & 1.5 & 112 & 330 & 62 & 0.08 \\
\hline $\mathrm{Be}$ & 2.27 & 5.1 & 0.5 & 2.98 & 6.75 & 3.22 & 0.58 \\
\hline $\mathrm{Ti}$ & 97.5 & 41.4 & 3.1 & 72.8 & 31.1 & 1.4 & 0.4 \\
\hline V & 176 & 70.2 & 5.4 & 131 & 52.6 & 1.1 & 0.08 \\
\hline $\mathrm{Cr}$ & 3640 & 1423 & 80 & 197 & 77.3 & 7.6 & 0.9 \\
\hline $\mathrm{Mn}$ & 8.7 & 3.2 & 0.3 & 137 & 50.8 & 1.2 & 0.2 \\
\hline $\mathrm{Fe}$ & 127 & 46.1 & 3.1 & 7030 & 2570 & 70 & 5 \\
\hline $\mathrm{Co}$ & bdl & bdl & & 569 & 197 & 6 & 0.02 \\
\hline $\mathrm{Ni}$ & bdl & bdl & & 1115 & 388 & 52 & 0.04 \\
\hline $\mathrm{Zn}$ & 358 & 111 & 9 & 819 & 256 & 30 & 0.3 \\
\hline Ga & 35.4 & 10.3 & 0.8 & 152 & 44.7 & 5.3 & 0.04 \\
\hline
\end{tabular}

$S D=$ standard deviation

$b d l=$ below detection limits 

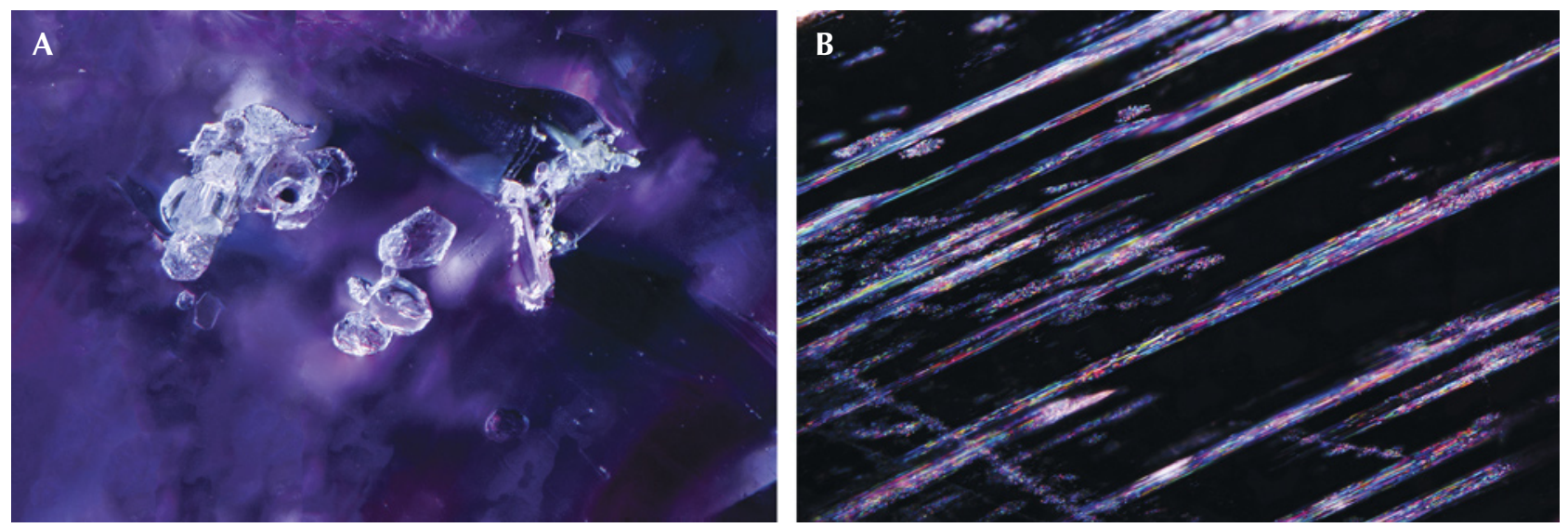

Figure 8. Inclusion scenes in spinel sample VN. A: Magnesite crystals that occasionally coexist in composite inclusions along with graphite (field of view $1.26 \mathrm{~mm}$ ). B: Needle-like inclusions (field of view $3.57 \mathrm{~mm}$ ). Photomicrographs by Aaron Palke.

polito et al. (2015; cobalt only): $\left({ }^{\mathrm{M}} \mathrm{Cr}^{3+}\right) 349.4365$, $387.3352,420.9564,531.5635,570.5204 ;\left({ }^{\mathrm{M}} \mathrm{V}^{3+}\right)$ 394.2329, 541.0837; $\left(\mathrm{M}^{\mathrm{F}}{ }^{3+}\right)$ 458.5660, 476.2484; $\left({ }^{\mathrm{T}} \mathrm{Fe}^{2+}\right)$ 374.2733，386.7225，406.9652，554.5731， 587.8204， 798.6127; $\quad\left({ }^{\mathrm{T}} \mathrm{Mn}^{2+}\right) \quad 428.2166 ; \quad\left({ }^{\mathrm{T}} \mathrm{Co}^{2+}\right)$ $552.6287,588.0105,630.7159$.

Raman Spectroscopy Analysis. Raman spectra of inclusions in the spinels were collected with a Renishaw inVia Raman microscope system. The Raman spectra of the inclusions were excited by a StellarREN Modu Ar-ion laser producing highly polarized light at $514 \mathrm{~nm}$ and collected at a nominal resolution of $3 \mathrm{~cm}^{-1}$ in the $2000-200 \mathrm{~cm}^{-1}$ range. Each spectrum was accumulated three times with a collection time of $10 \mathrm{~s}$ at $20 \times$ or $50 \times$ magnification. In many cases the confocal capabilities of the Raman system allowed inclusions beneath the surface to be analyzed.

\section{RESULTS}

Sample Descriptions. Samples VN and AF are transparent with few inclusions. Sample VN, $3 \mathrm{~mm}$ in thickness (later polished to $2.155 \mathrm{~mm}$ ), had a medium tone, strong saturation, purple hue, weak to moderate orange-red fluorescence under longwave $(365 \mathrm{~nm})$ ultraviolet radiation, and a very slight color change between daylight (standard 6500 $\mathrm{K}$ fluorescent bulb) and incandescent illumination (standard halogen incandescent bulb at $\sim 2700 \mathrm{~K}$ ); see figure 5, A and B. Sample AF, $5 \mathrm{~mm}$ in thickness (later polished to $4.486 \mathrm{~mm}$ ), had a medium tone, moderate saturation, and purple hue (figure 6) and was nonfluorescent when exposed to long- and short-wave UV.
Inclusions. The purple spinel from Vietnam contained several distinct mineral inclusions. Raman spectroscopy allowed the identification of several black platelets as graphite and several colorless minerals as magnesite, which are also known to occur in red gem spinel from Vietnam (Malsy et al., 2012). Occasionally, composite inclusions of graphite and magnesite were seen (figure 8A). Additional inclusions in sample VN were observed but could not be positively identified with Raman, such as platelet-like colorless crystals (potentially phlogopite crystals) and needlelike inclusions that resembled rutile inclusions (figure $8 \mathrm{~B}$ ) seen in other gem minerals. Among the inclusions seen in the Afghan spinel were fields of negative crystals (presumably hosting fluid inclusions), tiny black dust-like particles, and colorless mineral inclusions. Some of these inclusions were identified by Raman spectroscopy as phlogopite. The elongate inclusion in figure 9 was identified by Raman spectroscopy as an amphibole-group mineral, but the peaks overlapped with the background spinel signal, precluding conclusive amphibole species identification.

Chemical Composition. Spinel compositions were measured using EPMA and LA-ICP-MS, where the EPMA data (table 1) is used to provide major and minor element composition, including $\mathrm{Mg}$ for use as an internal standard for LA-ICP-MS.

The purple spinel from Vietnam (sample VN) contained significant concentrations of multiple chromophores (table 3): 593 ppma Cr, 17.9 ppma Co, 84.8 ppma V, and 2437 ppma Fe. The purple spinel from Afghanistan (sample AF) was very poor by comparison in most chromophore elements-namely Ni, Zn, 


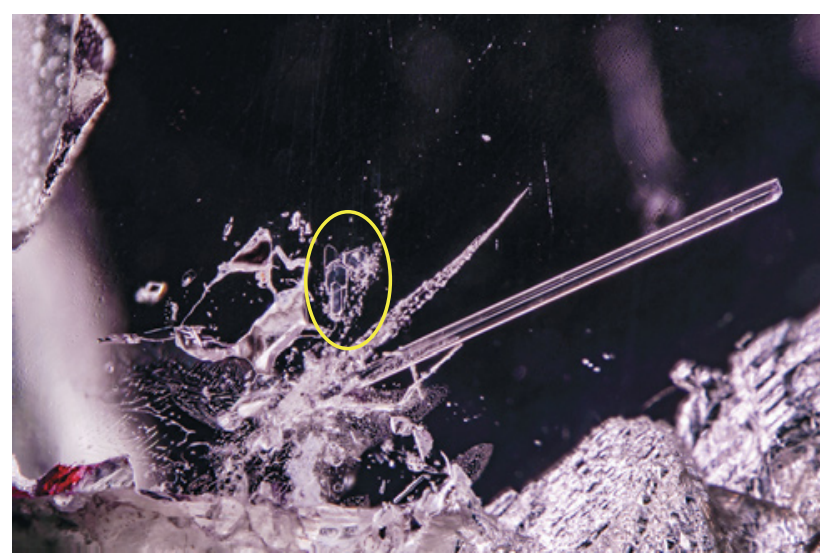

Figure 9. Pseudohexagonal platelets of phlogopite (circled in yellow) and secondary fluid inclusions, together with a prismatic amphibole, in spinel sample AF. Photomicrograph by Aaron Palke; field of view $4.79 \mathrm{~mm}$.

and $\mathrm{Ga}$ - but contained more Fe (3089 ppma) and $\mathrm{Mn}$ (56.8 ppma).

Absorption Spectra. In the absorption spectrum of sample VN, two transmission windows occurred between $\sim 430$ and $510 \mathrm{~nm}$ (blue-green range of visible spectrum), and above $650 \mathrm{~nm}$ (red range of the visible spectrum). The absorption was characterized by two broad peaks centered at approximately 390 and 545 $\mathrm{nm}$, in addition to a characteristic cobalt peak at $\sim 630$ $\mathrm{nm}$ (figure 10). The absorption spectrum profile for the purple spinel from Afghanistan was flatter than for the Vietnamese sample, with peaks at $558 \mathrm{~nm}$ (broad), 383 $\mathrm{nm}, 370 \mathrm{~nm}$, two small peaks at 455 and $475 \mathrm{~nm}$ in the trough between the former, and a significant and rapid increase in absorption at wavelengths below 360 $\mathrm{nm}$ (figure 10). The absorption bands are consistent with those of iron (D'Ippolito et al., 2015).

\section{DISCUSSION}

Color. Sample VN had characteristic absorption maxima attributed to $\mathrm{Cr}^{3+}$ at $\sim 530$ and $\sim 390 \mathrm{~nm} ; \mathrm{Co}^{2+}$ at $\sim 620 \mathrm{~nm}$ (the reference absorption is $630 \mathrm{~nm}$, from D'Ippolito et al., 2015); and ${ }^{\mathrm{T}} \mathrm{Fe}^{2+}$ (shoulder at $\sim 370$ $\mathrm{nm}$; figure 10; Andreozzi et al., 2019|. To better illustrate the color contribution of cobalt and other chromophores in this Vietnamese purple spinel, reference spectra of spinels colored by $\mathrm{Co}^{2+}$ and $\mathrm{Cr}^{3+}$ were used to perform scaled subtractions from the $\mathrm{VN}$ spectrum (reference peaks for $\mathrm{Co}^{2+}$ at $\sim 620 \mathrm{~nm}$ and $\mathrm{Cr}^{3+}$ at $\sim 389 \mathrm{~nm}$; similar to the method of Palke and Sun, 2018). The reference spectra (GIA-Co and GIA-Cr) showed imperceptible color contributions by other chromophores when scaled down for the subtraction, and therefore they did not noticeably reduce peaks from other chromophores in the resulting difference. The resulting subtracted spectra (figure 11) clearly demonstrated that sample VN was dominantly colored by both $\mathrm{Co}^{2+}$ and $\mathrm{Cr}^{3+}$, while the color contribution by ${ }^{\mathrm{T}} \mathrm{Fe}^{2+}$ (e.g., the peak at $374 \mathrm{~nm}$ ) was present but negligible. Color contribution by $\mathrm{V}^{3+}$ is possible and difficult to quantify due to peak overlaps with $\mathrm{Cr}^{3+}$, but when present it is relatively minor (see for example, absorption spectra of Cr-V-bearing spinels in Malsy and Klemm, 2010). A notable feature of the VN absorption spectrum is a relatively prominent "shoulder" at $~ 620 \mathrm{~nm}$, which demonstrates a noteworthy effect of $\mathrm{Co}^{2+}$ on the color of this purple spinel even without data processing. Sample VN is the first described example of natural purple spinel in which both $\mathrm{Cr}^{3+}$ and $\mathrm{Co}^{2+}$ are the prominent contributors to the coloration and are roughly equally weighted (e.g., similar absorption peak heights above background for each chromophore, resulting in a distinctly purple hue), as opposed to $\mathrm{Cr}^{3+}-\left(\mathrm{Fe}^{2+}, \mathrm{Fe}^{3+}\right)$-dominant or $\mathrm{Fe}\left(\mathrm{Fe}^{2+}, \mathrm{Fe}^{3+}\right)$ alone (e.g., Schmetzer et al., 1989; Malsy and Klemm, 2010). Kuksa et al. (2019) presented compositional data and a photograph of a Vietnamese spinel described as "bluish" (within the reference sample known as sample 5), which ap-

TABLE 3. LA-ICP-MS analyses of trace element concentrations in purple spinel samples.

\begin{tabular}{|c|c|c|c|c|c|c|c|}
\hline \multirow{3}{*}{$\begin{array}{c}\text { Sample } \\
\text { Color } \\
\text { No. of spots }\end{array}$} & \multirow{2}{*}{\multicolumn{3}{|c|}{$\begin{array}{c}\text { VN } \\
\text { Purple }\end{array}$}} & \multirow{2}{*}{\multicolumn{3}{|c|}{$\begin{array}{c}\mathrm{AF} \\
\text { Purple }\end{array}$}} & \multirow{3}{*}{$\begin{array}{c}\text { Detection } \\
\text { limit }\end{array}$} \\
\hline & & & & & & & \\
\hline & & 4 & & & 3 & & \\
\hline & Avg. & Avg. & SD & Avg. & Avg. & SD & \\
\hline & ppmw & ppma & ppma & ppmw & ppma & ppma & ppmw \\
\hline $\mathrm{Li}$ & 23 & 69 & 1 & 13 & 39 & 2 & 0.5 \\
\hline $\mathrm{Be}$ & 10 & 23 & 2 & 2 & 5 & 1 & 0.9 \\
\hline $\mathrm{Ti}$ & 31.6 & 13.6 & 1.9 & 37.3 & 15.9 & 2.1 & 5.8 \\
\hline V & 210 & 84.8 & 3.5 & 22.9 & 9.2 & 0.7 & 0.3 \\
\hline $\mathrm{Cr}$ & 1499 & 593 & 39 & 6.3 & 2.5 & 0.5 & $5.4^{*}$ \\
\hline$M n$ & 89.9 & 33.7 & 0.6 & 152.8 & 56.8 & 0.7 & 4.8 \\
\hline $\mathrm{Fe}$ & 6617 & 2437 & 24 & 8447 & 3089 & 10 & 5.2 \\
\hline $\mathrm{Co}$ & 51.4 & 17.9 & 0.3 & 5.6 & 1.9 & 0.1 & 0.2 \\
\hline $\mathrm{Ni}$ & 35.6 & 12.5 & 0.7 & 13.3 & 4.6 & 0.3 & 1.6 \\
\hline $\mathrm{Zn}$ & 10510 & 3310 & 110 & 214 & 67 & 5 & 7.3 \\
\hline Ga & 302 & 89 & 1 & 97 & 28 & 1 & 0.3 \\
\hline $\begin{array}{l}S D=\text { stan } \\
S c<1.5 p \\
{ }^{*} C r \text { detec }\end{array}$ & $\begin{array}{l}d \text { dev } \\
\text { w, Cu } \\
\text {, imit }\end{array}$ & $.7 p$ & 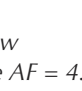 & nmp & & & \\
\hline
\end{tabular}




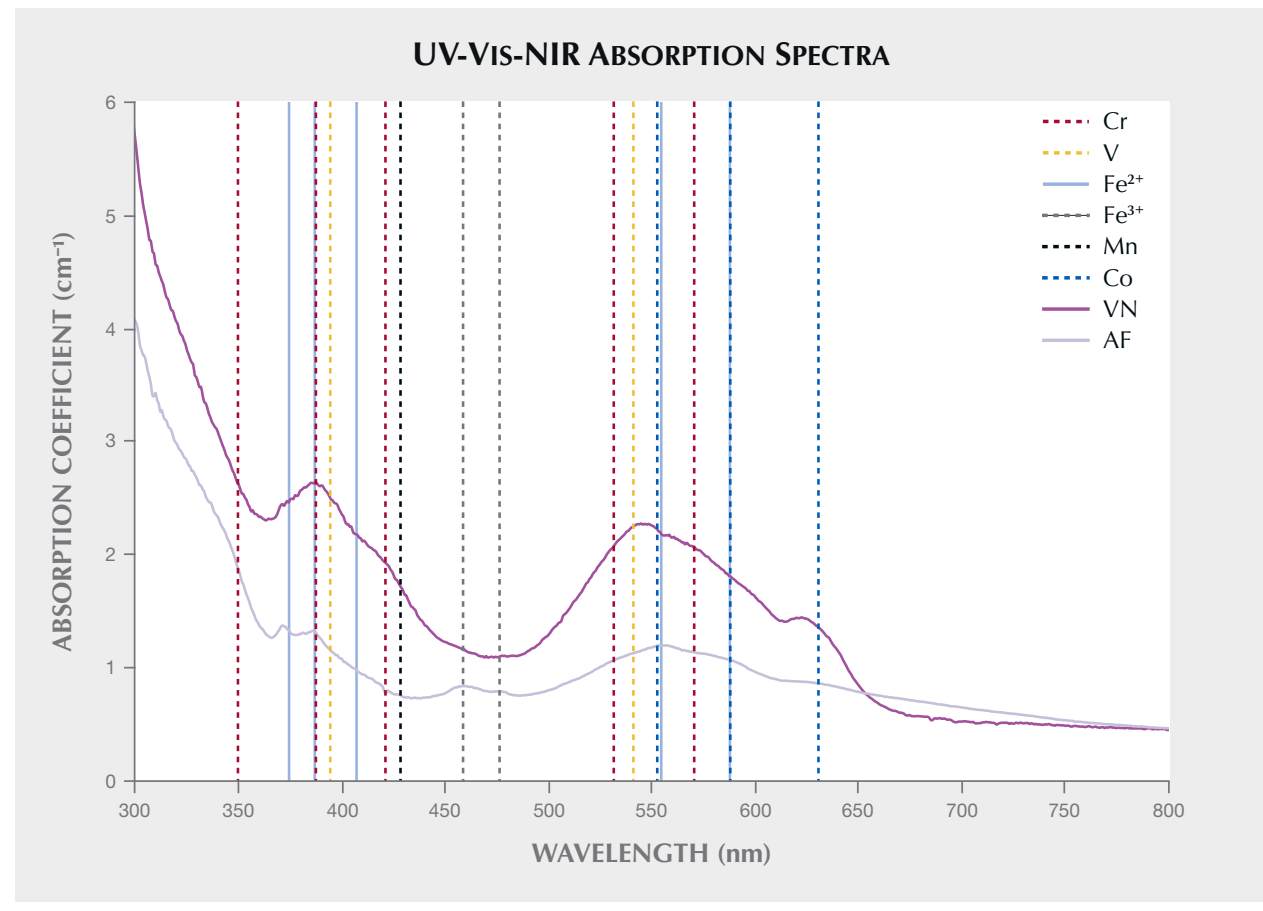

Figure 10. UV-Vis-NIR absorption spectra of spinel samples VN (purple) and AF (light purple). Chromophore absorption bands after D'Ippolito et al., $2015\left(\mathrm{Co}^{2+}\right)$ and $\mathrm{An}$ dreozzi et al., 2019 (other elements).

peared vivid blue with a slight purplish hue in the figure. This sample appeared dominantly colored by cobalt with subordinate chromium, and its chemical composition is discussed further below.

Purple spinel sample VN has a higher color saturation than purple sample AF (colored by ${ }^{\mathrm{T}} \mathrm{Fe}^{2+}$ with minor ${ }^{\mathrm{M}} \mathrm{Fe}^{3+}$, which is shown by the greater peak-trough difference in absorption spectrum (figure 10). This is evidently due to the greater visible light absorption by $\mathrm{Cr}^{3+}$ and particularly $\mathrm{Co}^{2+}$ per unit of concentration compared to the predominant iron chromophore, $\mathrm{Fe}^{2+}$ (e.g., $~ 20 \times$ molar absorptiv-

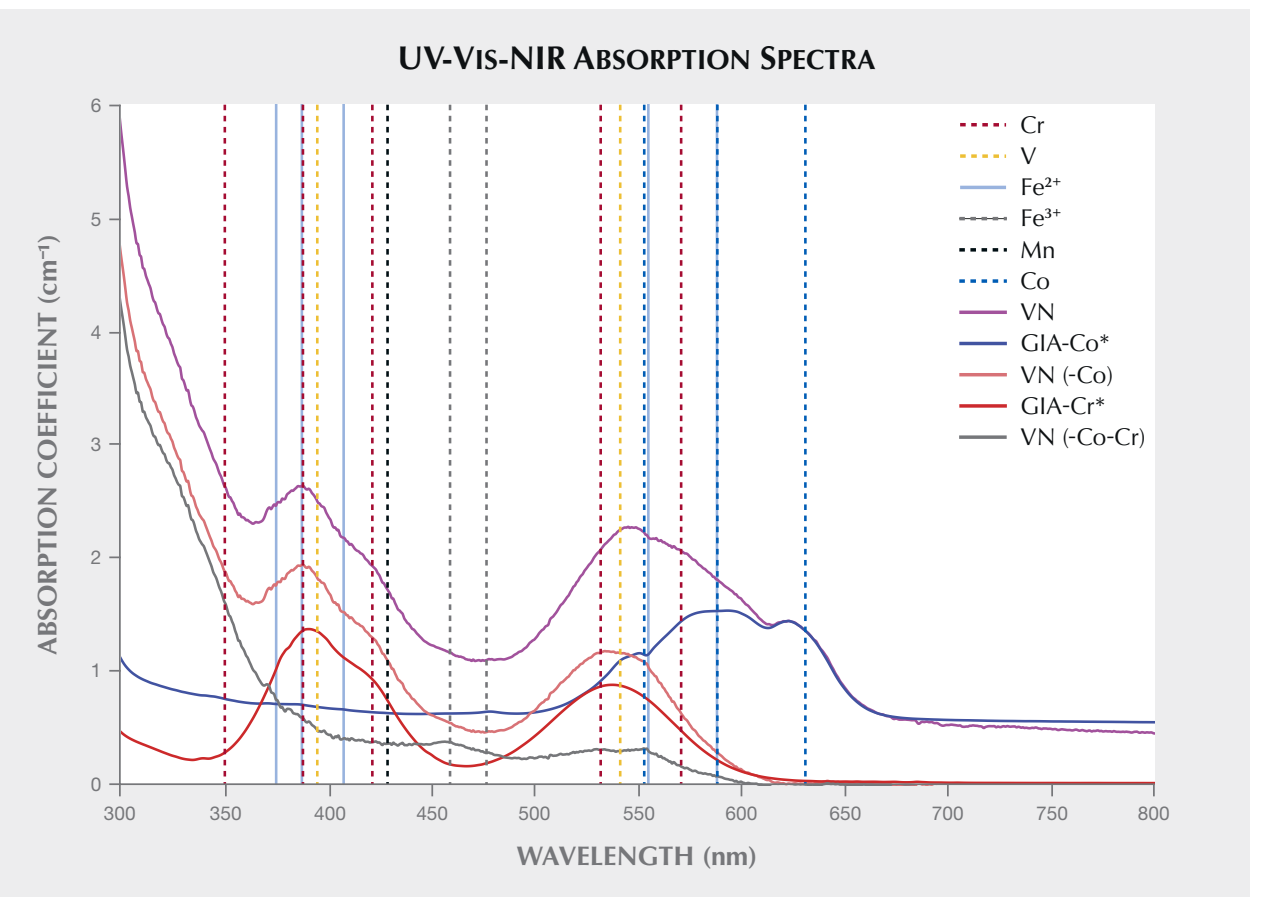

Figure 11. UV-Vis-NIR absorption spectra for VN (purple), VN with scaled subtraction of a reference spectrum of Co-bearing vivid blue spinel (pink), and scaled subtraction of both Corich and Cr-rich spinel reference spectra (gray). The Co-dominant (GIACo, scale factor 0.095 , blue) and $\mathrm{Cr}$-dominant (GIA-Cr, scale factor 0.082, red) spectra are included for comparison. Chromophore absorption bands after D'Ippolito et al., 2015 (Co) and Andreozzi et al., 2019 (other elements). 
ity of $\mathrm{Co}^{2+}$ relative to $\mathrm{Fe}^{2+}$, Chauviré et al., 2015), but could also be accentuated by VN's red fluorescence. Therefore, the combination of elevated cobalt (17.9 ppma) and chromium (593 ppma) concentrations as the dominant chromophores result in an attractive purple color that is more saturated, with stronger red and blue hues, than spinel colored primarily by ${ }^{\mathrm{T}} \mathrm{Fe}^{2+}$. Sample 3 from Kuksa et al. (2019), a brownish purplish red spinel from Vietnam, also serves as an interesting comparison to purple sample VN. Sample 3 contained a similar concentration of $\mathrm{Cr}$, slightly over half the Co concentration, and four times the Fe concentration. Unlike sample VN, which is purple primarily due to $\mathrm{Cr}$ and Co, Kuksa et al.'s sample 3 was brownish purplish red, likely representative of a color defined primarily by $\mathrm{Cr}$ and Fe. Kuksa et al. (2019), did not measure light absorption, so the causes of color have not been quantified.

Spinel sample VN represents the "missing link" in Schmetzer et al.'s (1989) spinel color/chromophore diagram, being roughly intermediate between the red $\left(\mathrm{Cr}^{3+}\right)$ and blue $\left(\mathrm{Co}^{2+}\right)$ end members.

Chromophore Trace Elements in Gem Spinels. Cobalt-enriched spinel, generally vivid blue in color, typically contains low $\mathrm{Cr}$ concentrations $\mid<60 \mathrm{ppma}$; Hanser, 2013; Chauviré et al., 2015; Kuksa et al., 2019), with two outliers known from Vietnam. One Cr-rich outlier (1111 ppma Cr and 1236 ppma Co; Chauviré et al., 2015) reported from Vietnam is vivid blue in color with no visible reddish or purplish hues, indicating that cobalt has a much higher molar absorptivity than chromium, similar to cobalt's higher molar absorptivity relative to iron (Chauviré et al., 2015). The other outlier, sample 5 of Kuksa et al. (2019), has a vivid slightly purplish blue color. Purple spinel sample VN appears to be approximately compositionally intermediate between Cr-dominant pink/red spinels and Co-dominant blue spinels, whereas sample 5 is intermediate between sample $\mathrm{VN}$ and Co-dominant blue spinels, as shown in a plot comparing the relative concentrations of $\mathrm{Co}$ to $\mathrm{Cr}$, and $\mathrm{Co}$ to Fe (figure 12).

Most Cr-enriched spinels (red, pink, magenta, and orange gem spinels) are very poor in cobalt ( $\mathrm{Co}<6$ ppma; Malsy and Klemm, 2010), and thus their color is largely determined by $\mathrm{Cr}^{3+}, \mathrm{V}^{3+}$, and $\mathrm{Fe}\left(\mathrm{Fe}^{2+}, \mathrm{Fe}^{3+}\right)$ concentrations (Schmetzer et al., 1989; Andreozzi et al., 2019|. Among spinel trace element compositions recorded in the scientific literature, only Kuksa et al.'s (2019) sample 3 has a cobalt-to-chromium ratio similar to that of sample VN. However, their sample 3 is poorer in cobalt overall (10.6 ppma) and four times richer in iron than VN. Thus, sample VN is primarily an intermediate between a Cr-dominant red spinel and a Co-dominant blue spinel, while sample 3 is intermediate between spinels having $\mathrm{Cr}^{3+}$ and $\mathrm{Fe}\left(\mathrm{Fe}^{2+}, \mathrm{Fe}^{3+}\right)$ as the dominant chromophores, respectively. This also correlates with their relative positions in a chemistry-based discrimination plot (figure 12). Unlike Kuksa et al.'s sample 3, VN has a sufficiently high $\mathrm{Co}^{2+}$ concentration and low $\mathrm{Fe}\left(\mathrm{Fe}^{2+}, \mathrm{Fe}^{3+}\right)$ concentration so as to be colored strongly saturated purple with an absorption spectrum showing clear characteristic absorption maxima from both $\mathrm{Cr}^{3+}$ and $\mathrm{Co}^{2+}$.

While sample VN plots intermediate to Cr-dominant and Co-dominant spinels in a plot of $\mathrm{Co} / \mathrm{Cr}$ vs. $\mathrm{Co} / \mathrm{Fe}$ (figure 12), sample AF plots in the iron-dominant portion (Cr-poor, high $\mathrm{Co} / \mathrm{Cr}$, low $\mathrm{Co} / \mathrm{Fe}$ ). Overall, gem spinels appear to be easily differentiated according to dominant chromophores using a chemical discrimination plot of $\mathrm{Co} / \mathrm{Cr}$ vs. $\mathrm{Co} / \mathrm{Fe}$, although this plot will not work well for spinel in which $\mathrm{V}^{3+}$ is the dominant chromophore, or for spinel based on $\mathrm{Fe}^{2+} / \mathrm{Fe}^{3+}$ relative abundance or with elevated Fe concentrations (e.g., green and black Fe-rich spinels; Hålenius et al., 2002).

\section{CONCLUSIONS}

The purple spinel sample from the Khao Ka placer deposit in the Luc Yen district of Vietnam (sample VN) was colored primarily by cobalt (17.9 ppma) and chromium (593 ppma), with minor iron (2437 ppma) and possibly vanadium (84.8 ppma). It contained significantly more cobalt than typical chromium-enriched gem spinels ( $<6$ ppma Co). The similarly important contributions of cobalt and chromium to visible light absorption, the first such natural example to be reported, resulted in a purple of higher saturation than in the purple spinel sample from Afghanistan, which only had an iron chromophore (3089 ppma Fe; <10 ppma V, Cr, and Co). In the Vietnamese purple spinel, a relatively low iron concentration was also essential in creating an attractive saturated color, as shown by a comparison with a similar but more iron-rich spinel from the same region.

The purple spinel from Vietnam was enriched in chromium, cobalt, vanadium, gallium, and zinc relative to the sample from Afghanistan, which was poor in all chromophore elements with the exception of being slightly richer in iron and manganese. 


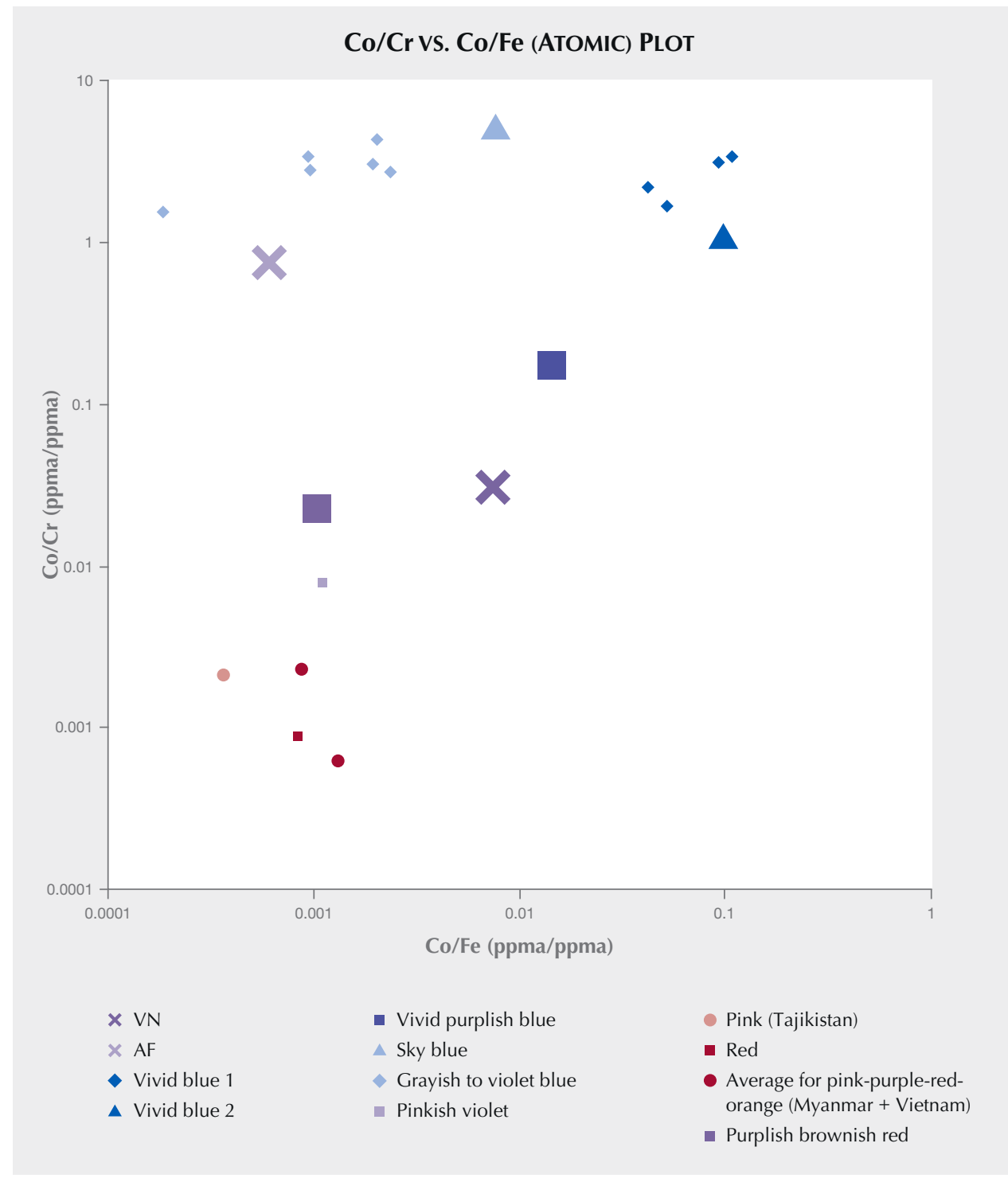

Figure 12. Co/Cr vs. $\mathrm{Co} / \mathrm{Fe}$ (atomic) plot discriminating between spinel of different dominant chromophores, categorized by color category. Data sources: Vivid blue 1: Kuksa et al., 2019; Chauviré et al., 2015 (SATBLU); Hanser, 2013. Vivid blue 2: Sample GIA-Co (present study). Vivid purplish blue: Kuksa et al., 2019 (sample no. 5). Sky blue: Chauviré et al., 2015. Grayish to violet blue: Chauviré et al., 2015 (GREBLU); Hanser 2013; D'Ippolito et al., 2015 (Nat. 2). Pinkish violet: Kuksa et al., 2019 (sample no. 1). Pink (Tajikistan) and average for pink, purple, red, and orange spinel from Myanmar and Vietnam: Malsy and Klemm, 2010. Red: Kuksa et al., 2019. Purplish brownish red: Kuksa et al., 2019 (sample no. 3). Sample GIA$\mathrm{Cr}$ is excluded from the plot due to being an extreme outlier with $\mathrm{Co} / \mathrm{Cr}$ $<4.85 \times 10^{-6}$.

The Vietnamese purple spinel represents an approximate intermediate between natural spinel populations colored dominantly by chromium and those colored dominantly by cobalt. A vivid purplish blue spinel from Vietnam reported by previous authors represents an intermediate more strongly weighted toward cobalt. Gem spinels of different colors are easily differentiated by chemical composition using a discrimination plot of $\mathrm{Co} / \mathrm{Cr}$ vs. $\mathrm{Co} / \mathrm{Fe}$, but this is valid for spinel not dominantly colored by $\mathrm{V}^{3+}$ or containing elevated concentrations of Fe (e.g., green and black Fe-rich spinel).
ABOUT THE AUTHORS

Dr. Belley is an assistant professor in the Department of Earth Sciences at Memorial University of Newfoundland in St. John's, Canada. Dr. Palke is senior manager of research at GIA in Carlsbad, California.

\section{ACKNOWLEDGMENTS}

Helpful comments from the peer reviewers improved the quality of the manuscript. We thank the Gübelin Gem Lab (Lucerne, Switzerland) for assistance and use of facilities for preliminary spectroscopic analyses. We are grateful to Marg Amini (University of British Columbia) for support with LA-ICP-MS, Ikram Muhammad for donating the spinel from Afghanistan, and Geir Gussiås for providing samples, information, and photographs. 


\section{REFERENCES}

Andreozzi G.B., D'Ippolito V., Skogby H., Hålenius U., Bosi F. (2019) Color mechanisms in spinel: a multi-analytical investigation of natural crystals with a wide range of coloration. Physics and Chemistry of Minerals, Vol. 46, No. 4, pp. 343360, http://dx.doi.org/10.1007/s00269-018-1007-5

Armstrong J.T. (1988) Quantitative analysis of silicate and oxide minerals: Comparison of Monte-Carlo, ZAF, and Phi-Rho-Z procedures. In D.E. Newbury, Microbeam Analysis, pp. 239-246.

Belley P.M., Groat L.A. (2019) Metacarbonate-hosted spinel on Baffin Island, Nunavut, Canada: Insights into the origin of gem spinel and cobalt-blue spinel. Canadian Mineralogist, Vol. 57, pp. 147-200.

Boehm E. (2017) Gem Notes: Purple spinel from Badakhshan, Afghanistan. Journal of Gemmology, Vol. 35, No. 8, pp. 694696.

Chauviré B., Rondeau B., Fritsch E., Ressigeac P., Devidal J.-L. (2015) Blue spinel from the Luc Yen district of Vietnam. Ge G, Vol. 51, No. 1, pp. 2-17, http://dx.doi.org/10.5741/GEMS.51.1.2.

D’Ippolito V., Andreozzi G.B., Hålenius U., Skogby H., Hametner K., Günther D. (2015) Color mechanisms in spinel: cobalt and iron interplay for the blue color. Physics and Chemistry of Minerals, Vol. 42, No. 6, pp. 431-439, http://dx.doi.org/10.1007/s00269-0150734-0

Hålenius U., Skogby H., Andreozzi G.B. (2002) Influence of cation distribution on the optical absorption spectra of $\mathrm{Fe}^{3+}$-bearing spinel s.s.-hercynite crystals: Evidence for electron transitions in ${ }^{\mathrm{VI}} \mathrm{Fe}^{2+}-\mathrm{VI}^{\mathrm{V}} \mathrm{Fe}^{3+}$ clusters. Physics and Chemistry of Minerals, Vol. 29, pp. 319-330, http://dx.doi.org/10.1007/s00269-0020240-z

Hanser C.S. (2013) Blue Co-spinel from Luc Yen, Vietnam: a spectroscopic study. Bachelor's thesis, University of Freiberg, Germany, $50 \mathrm{pp}$.
Jochum K.P., Nohl U., Herwig K., Lammel E., Stoll B., Hofmann A.W. (2005) GeoReM: a new geochemical database for reference materials and isotopic standards. Geostandards and Geoanalytical Research, Vol. 29, No. 3, pp. 333-338, http://dx.doi.org/10.1111/j.1751-908X.2005.tb00904.x

Kuksa K.A., Sokolov P.B., Marakhovskaya O.Y., Gussiås G.A. (2019) Mineralogy, geochemistry and genesis of the Luc Yen noble spinel deposit, Vietnam. Mineralogy, Vol. 5, pp. 56-69, http://dx.doi.org/10.35597/2313-545X-2019-5-3-56-69 [in Russian].

Malsy A., Klemm L. (2010) Distinction of gem spinels from the Himalayan Mountain Belt. Chimia, Vol. 64, No. 10, pp. 741746, http://dx.doi.org/10.2533/chimia.2010.741

Malsy A.K., Karampelas S., Schwarz D., Klemm L., Armbruster T., Tuan D.A. (2012) Orangey-red to orangey-pink gem spinels from a new deposit at Lang Chap (Tan Huong-Truc Lau), Vietnam. Journal of Gemmology, Vol. 33, No. 1, pp. 19-27.

Palke A.C., Sun Z. (2018) What is cobalt spinel? Unraveling the causes of color in blue spinels. Ge G, Vol. 54, No. 3, p. 262.

Paton C., Hellstrom J., Paul B., Woodhead J., Hergt J. (2011) Iolite: freeware for the visualization and processing of mass spectrometric data. Journal of Analytical Atomic Spectrometry, Vol. 26, No. 12, pp. 2508-2518, http://dx.doi.org/10.1039/clja10172b

Rocholl A. (2007) Major and trace element composition and homogeneity of microbeam reference material: basalt glass USGS BCR-2G. Geostandards and Geoanalytical Research, Vol. 22, No. 1, pp. 33-45, http://dx.doi.org/10.1111/j.1751908X.1998.tb00543.x

Schmetzer K., Haxel C., Amthauer G. (1989) Colour of natural spinels, gahnospinels and gahnites. Neues Jahrbuch für Mineralogie, Abhandlungen, Vol. 160, pp. 159-180.

Shigley J.E., Stockton C.M. (1984) 'Cobalt-blue' gem spinels. $G \uplus G$, Vol. 20, No. 1, pp. 34-41, http://dx.doi.org/10.5741/GEMS.20.1.34

\section{CONGRATULATIONS

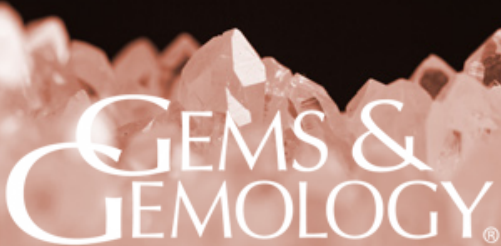 \\ This year, readers from all over the world participated in the 2021 Gems \& \\ Gemology Challenge. Entries arrived from around the world as readers tested their gemological knowledge by answering questions listed in the Spring 2021 issue. Those who earned a score of $75 \%$ or better received a GIA Certificate of Completion recognizing their achievement. Participants who scored a $96 \%$ or higher are listed below.}

\section{G\&G Challenge Winners}

Russia

Sergey Ivasenko

\section{Ukraine}

Nataliya Vovk

United Kingdom

Bingham Henderson

Ana Lucia Tres

\author{
United States \\ Kenneth Fogelberg \\ Heather Gallacher \\ Jessica Kramer \\ Jana Miyahira-Smith \\ Tim Richardson \\ Shelly Verwymeren \\ Ryan Waddell
}

\section{Answers}

See pages 50-51 of the Spring 2021 issue for the questions.

1 (a), 2 (b), 3 (b), 4 (c), 5 (b), 6 (c), 7 (d), 8 (d), 9 (c), 10 (c), 11 (b), 12 (d), 13 (b),

14 (a), 15 (b), 16 (b), 17 (c), 18 (a), 19 (c), 20 (b), 21 (b), 22 (b), 23 (a), 24 (a), 25 (d) 